Interdisciplinary Studies of Complex Systems

No. 13 (2018) 57-65

(C) L. Savenkova, D. Svyrydenko

\title{
Academic Mobility and Academic Migration ISSUES: THE CASE OF UKRAINIAN HigheR EDUCATION
}

\author{
Liudmyla Savenkova, Denys Svyrydenko ${ }^{2}$
}

\begin{abstract}
The article demonstrates the globalization and regional dimension of the problems of academic mobility as well as academic migration at the Ukrainian education environment. The authors' approach is based on the fact that the dialectics of globalization and regionalization has a significant influence on the essence of the processes of academic mobility and academic migration. The theoretical study and analysis of educational policy have demonstrated the need for harmonization of these processes taking into account current geopolitical challenges. The authors have explored the "order of the day" of problems related to academic mobility and academic migration, taking into account current geopolitical challenges, trying to identify the perspective directions of study of this problem.
\end{abstract}

Keywords: migration, academic migration, academic mobility, students' adaptation, brain drain, globalization, European Higher Education Area.

\section{Introduction}

The intensive development of mobility opportunities all around the world the expansion of not only economic, scientific, but educational contacts between countries, communication changes in the informational milieu also put the issue of adaptation of academic migrants in the conditions of residence in selected countries for education. Internationalization of higher education significantly increases the number of people who want to study abroad in more developed countries.

The presence of students from other countries at universities shows the inclusion of Ukraine into the international global educational system. Participation in the world educational process is one of the conditions for the successful development of a higher educational institution. Therefore, the education of abroad students occupies a significant place among the various activities of Ukrainian universities. This activity fits the logic of globalization and conceptualized in the educational practice by the concepts of "academic mobility" as well as "academic migration". These phenomena fit into the logic of developing the European Higher Education Area (EHEA) and the European Research Area (ERA), while the processes of academic mobility and migration are key tools for their implementation. These tendencies are appropriately enshrined in the European Union educational program documents.

\footnotetext{
${ }^{1}$ National Pedagogical Dragomanov University, lvsav59@gmail.com

${ }^{2}$ National Pedagogical Dragomanov University, denis_sviridenko@ukr . net
} 
At the same time, in parallel with the tendencies of globalization, complex processes of academic migration, caused by the geopolitical situation in the country, take place in Ukraine. In recent years, the socio-cultural space of Ukraine is under the influence of complex contradictions of a geopolitical nature, initiated by an armed military conflict in the East of Ukraine and the annexation of Crimea. These contradictions logically initiated the processes of moving (evacuating) institutions of higher education and scientific institutions into a controlled territory in order to preserve the intellectual, economic and human potential of the regions that emerged as the arena for the implementation of the strategies of the hybrid war. About thirty institutions of higher education and scientific institutions made a forced move from the zone of military conflict following the desire to stay a part of the Ukrainian scientific and educational space.

At the same time, material facilities (campus with educational buildings, scientific laboratories, etc.), as well as the presence of a part of teaching, training, support and student staff, allowed to create institutions of higher education and scientific institutions in uncontrolled territories. Based on such facilities, the own scientific and educational space is built up at the non-controlled territories from 2014. Thus, the institutions were not moved in their integrity but separated, creating "separated" institutions and the Ukrainian educational and scientific space itself lost its integrity.

The authors of the article aim to explore the complex dialectic of globalization and regionalization trends at the processes of academic mobility and academic migration. The authors proceed from the understanding that this article is merely an "order of the day" of academic mobility and academic migration at the Ukrainian higher education system. The problem further analysis requires a series of studies using statistical methods, conducting in-depth interviews and focus groups.

\section{Mobility Turn as Cultural Background of Academic Mo- bility and Academic Migration Processes}

As already mentioned above, the article analyzes the problems of academic mobility and academic migration in Ukrainian higher education. Addressing this problem is caused by the need to determine the place of global and regional trends in these processes in order to make their implementation more controlled. Indeed, the being of modern society and education is increasingly beginning to be mobile. At a contemporary social and humanities studies, broad discussion concerning the mobility trends takes place over the past decade. In order to demonstrate the scale of the spread of the ideology of mobility in society using "language of numbers", we turn to the indicators proposed by Ossi Naukkarinen, the Finnish researcher on the mobility problems: "In 1950 there were 53 million cars in the world; now there are more than 500 million, and according to some estimates, over 700 million. And people do use them. In Finland, which is fairly typical in this respect, the average of the private car is driven more than 10000 kilometres per year, which is over ten times more than in 1950. The growth of air traffic is even more astonishing. In 1950, 28 billion passenger kilometres were flown by the world's aeroplanes. Today, the figure 
is almost 3000 billion - over a hundred times more. International business has also grown, which means greater numbers of objects are transported from one place to another and more currency transactions conducted" [16].

The key idea of this discussion is the awareness and further conceptual development of the concept of "mobility turn" resulting in a transformation of ideas about space and time at a contemporary society, which undergoes the radical changes to the established principles of social interaction. Indeed, mobility is a sign of the overwhelming majority of modern social phenomena: from economics and communication systems to approaches in modern education. Thomas Faist conceptualizes the essence of mobility turn in the following way: "A new paradigmatic turn has reached migration studies, the mobility turn. Following on from many turns in the recent past, such as the linguistic turn, the cultural turn and the spatial turn, the mobility turn seems to be the newest effort in diagnostic descriptions of modern society. Like other turns, the mobility turn generalizes one aspect of contemporary society to the detriment of other features. While such a turn may usefully highlight various forms of spatial mobility, it cannot be fruitfully employed unless the scholars working with this paradigm critically reflect underlying political assumptions about the nexus between spatial and social mobility. Moreover, any analysis of spatial and social mobilities needs to go beyond descriptions and start accounting for the mechanisms underlying the production of social inequalities" [8, p. 1637].

Indeed, the issue of mobility does not simply become a key methodological tool but also enters its ontological essence in the "heart" of the modern world the phenomenon of the movement of elements of the social world is at the "heart" of modern social transformations. Consequently, the scientists were aware of the importance of displacements in modern society and throughout the history of mankind, but now it is comprehended as one of the foundations of modern everyday being, basic value, policy instrument, etc.: "Contemporary society lives at "the coordinates" of mobility and modern individual needs to transform one's own everyday practices to stay at the advance-guard of the social development, to perform successful carrier steps etc. The reports of some international organizations are demonstrated, that at the 21-th century life success depends form the people's ability to build the life strategies (as well as educational ones) taking into account the mobility tendencies at the modern society" [24, p. 103].

Thus, as a response to the adoption of a mobility turn in all the spheres of social life, the processes of academic mobility and academic migration are gaining considerable significance in the higher education system. At the same time, the authors would like to emphasize that the phenomenon of "academic mobility" as well as "academic migration" have arisen at the tradition of higher education since the founding of the first universities in the Middle Ages. The current quantitative and qualitative surge of mobility trends has led to their unprecedented updating in the global higher education area. 


\section{Global and Regional Dimension of Academic Mobility and Academic Migration Processes}

In the introduction, we emphasized that any complex social phenomena are implemented in accordance with the complex logic of globalization and regionalization. Academic mobility and academic migration are no exception. Let's consider how the processes of globalization of higher education intensify the mobility trends at Ukrainian higher education. Indeed, globalization contributes to increasing the intensity of migration, the erosion of borders between states, which leads to the formation of supranational social structures, socalled multicultural societies as well as multicultural educational environments in higher education. At the same time, mobility is also a tool for ensuring the negative phenomenon of "brain drain", which should also be considered in the study of positive prospects for academic mobility and academic migration: "Global talent mobility, accompanied by such concepts as 'brain drain', 'brain gain', 'brain exchange' and 'brain circulation', has drawn attention from both researchers and policy-makers. Research into, and policies concerned with, the movements of high skills, including university academics, are largely from economic perspectives on globalization. Inquiries are framed by concerns for national economic growth; the notion that, 'human capital translates into economic capital that translates into national economic growth and competitiveness'... Brain drain assumes that people who leave one country for another will never return, and that their movement is nonreversible. These unilateral flows, described as a loss of talent, are often viewed as having negative effects on the source countries which have made an educational investment in scholars who ultimately leave their home countries" [4, p. 25].

Under the influence of globalization, Ukrainian universities seek to attract a large number of foreign students in a fierce competition while addressing the issue of achieving a high level of intercultural understanding, striving to increase the intensity of interaction between representatives of different cultures, contributing to raising the level of education of foreign students (citizens of developing countries). At the context of global society transformation, higher education policy tries to take into account the needs of different groups that provide the development of a higher school, state structures, consumers of educational services, etc., which requires the formation of new (internationally) benchmarks and standards in the field of education which would be based on the qualitative theoretical foundation: "The blurring of distinction, the breadth of opportunities for individualization and realization of freedoms, initiates the problem of distorting the deep essence of some sociocultural phenomena. The Ukrainian sphere of higher education in this context is demonstrative: Ukraine has been a participant of the Bologna process for more than ten years; however, the nature of the implementation of its ideas acquires a wide range of signs from imitative to pathological" [13, p. 363-364].

Since both authors work at the National Pedagogical Dragomanov University, the empirical base that guided the direction of theoretical research was the processes of academic mobility and internationalization that took place in the educational environment of this university at 2017. The geography of the countries of the foreign students at the National Pedagogical Dragomanov University is represented by countries such as China, Turkmenistan, Azerbaijan, 
Belarus, Georgia, Italy, Moldova, Poland, Russia, Turkey, India, Uzbekistan, Syria, Israel, Iran, Portugal, etc. In total, the university has 388 international students, including 251 students, 100 postgraduate students, and 37 students in the preparatory department.

As we demonstrated, the educational environment of the university has a pronounced multicultural nature and its productive functioning is a separate research problem. In addition, academic mobility is realized not only by students, but also by lecturers and researchers, creating a separate problem and research field: "More and more, academics are mobile, and becoming transnational, opting for international academic career development... The socio-professional networks of transnational academics and their embodied spatial knowledge are not yet seriously analyzed empirically. Is this a new academic profession? An academic profession in which all members are multilingual, regardless of discipline, gender, age, region of origin and so on? Transnational identities are being formed. At the moment we cannot even describe them systematically - even though we are beginning to understand the discourses of neoliberalism and regional homogenization which are invoked to increase their existence" [11, p. 403].

As we see, Ukraine is trying to fit its status of responsible "player" of the global educational area implementing the key provisions of the Bologna Declaration and other documents aimed at implementing globalization trends in higher education. At the same time, the problematic current socio-cultural (geopolitical) situation distinguishes Ukraine from other countries that carry out transit and active modernization of higher education in accordance with high European standards. These are complex processes of a geopolitical nature that create instability in terms of the territorial integrity of Ukraine (annexation of Crimea and military conflict in the East of Ukraine) which actualizes a specific, regional dimension of the processes of academic migration. As a result of the geopolitical conflict, many universities with part of the state and students carried out an act of forced migration similar to forced migration from zones of military conflicts: "This conflict caused large-scale migration processes. The millions of Ukrainian people become the subjects of migration trying to escape from the direct military activity at their cities. The Ukrainian politicians also understood the need of saving the social and intellectual capital of the regions. At the result, most of the scientific and education institutions performed the migration procedure too. However, this migration had a special nature: the institutions migrated without facilities and resources; the stuff of migrated institutions was not full too" [23, p. 129].

\section{The Problem of Adaptation at Other Social, Cultural and Educational Environment}

At the previous sections of the article, we demonstrated the peculiarities of the implementation of the ideology of academic mobility and academic migration at the global and regional levels. At the same time, we did not study the problems, which had arisen in Ukrainian higher education area in connection with these tendencies. Based on the logic of the study's deployment, the problem of adaptation of both foreign students and internally displaced persons (students, workers of the displaced institutions of higher education) should be reviewed. 
Taking into account the desire of the displaced universities to become a new clusters of Ukrainian higher education system ("from scratch"), they begin to develop a strategy for development in the Ukrainian space of higher education taking into account the following fact: "The tragic bloody experience of territorial disintegration could be interpreted as a painful evolutionary step. At the result of external influence, the group of students, teachers and administrators can become a social capital for new educational institutions starting one's activity "tabula rasa". These people are firm to the values of university, firm to the European values such as freedom and democracy. They are firm to own Motherland. Thus, they may become a fundamental spiritual and intellectual resource for these institutions" [23, p.134]. In our opinion, it is sensible to remember the history of University of Cambridge appearing almost eight centuries ago. It appeared as a response to the socio-cultural challenges of the 13th centuries as a desire to avoid non-constructive educational practices and socio-cultural challenges of that time and place (Oxford) becoming a hub for innovation and democratic transformation.

Having carried out a revision of the globalization and regional challenges of the Ukrainian higher education system, we will consider the real problem of harmonizing the communicative space of Ukrainian higher education where complex modernization processes are taking place in response to the demands of worldwide and regional tendencies. At the same time, we would like to emphasize that regional migration processes have more or less dominant role for the development of strategies for the development of higher education in Ukraine: "The academic mobility is a demonstration of a wide range of human freedoms - the freedom to choose a place of study, the right to free movement, the academic freedom, etc. Such an understanding of this phenomenon harmoniously fits into the context of students treatment as creative individuals, who aspire to develop and actualize their potential in getting a higher education, being declared as one of the fundamental principles of the modernization of higher education in Ukraine" [13, p. 317].

In the article, the authors tried to emphasize the fact that Ukraine is a special socio-cultural landscape for the implementation of the principles of academic mobility and academic migration. At the same time, analysis of the educational policy of recent years makes it possible to distinguish between the specific tendency that looks like a simulation of the modernization of higher education in Ukraine. Ukraine signed the Bologna Declaration in 2005, however, the Model Provision on Academic Mobility was developed by the Ministry of Education and Science of Ukraine only in 2014.

This fact indicates, on the one hand, the lack of real mechanisms for ensuring academic mobility, and, on the other hand, the lack of normative documents to address complex processes of adaptation of foreign students and internally displaced persons. At the same time, the issue of adaptation of representatives of different cultures, religions and, in the context of current geopolitical challenges, is an important challenge that should be regulated at the legislative level: "Travelling knowledge is not simply a case of edges versus empires of knowledge or vice versa. When an intellectual travels from empires of knowledge to the edges, or indeed when they travel from the edges to empires of knowledge, they will always bring intellectual baggage with them" [9, p. 637]. 
Within our research, there is a need to emphasize the contradictions which exist at the multicultural Ukrainian higher education environment. On the one hand, there are the presenters of various cultural traditions of religious beliefs, and on the other hand, even within the same country, we see the contradictions of communication between the Ukrainians, which are trying to integrate internally displaced persons, by the same persons. The new socio-cultural environment causes difficulties adapting also due to the perception of foreigners by university staff that do not have special training to work with such a category of students. Linguistic and cultural adaptation gets much faster when foreign students communicate intensively with local students, for example, in dormitories. It helps to establish relationships with other students, exchange information, improve language skills, which greatly increases the efficiency of learning.

The growing number of foreign students and significant funds entering the higher education system of Ukraine make incoming mobility an important branch of educational exports, while the foreigners themselves are the category whose interests must be taken into account and protected. International students sometimes encounter big difficulties in social adaptation. As it has already noted, this is isolation or the possibility of communicating with compatriots only due to the low level of knowledge of a foreign language, the inadequate involvement of mobile students in extra-curricular activities, student self-government bodies [14].

Taking into account the challenges initiated by displaced universities and internally displaced persons (academic community representatives), some groups are opposed to dominant discourses, enhanced by prejudice and clichés, which take root in the unproductive tradition of geographical determinism within Ukraine. In parallel, a large number of foreign students from different countries of the world come to Ukraine every year to study at higher educational establishments. In total, the geography of the countries, where students go, includes about 148 states: according to the Ministry of Education and Science of Ukraine, foreigners are studying at 228 of Ukrainian universities [15]. The Minister emphasizes that only over the past two years the number of Ukrainian higher education institutions where foreign students are study increased from 185 to 228: in 2017 almost 40000 of invitations to education were issued, which is twice as much as in 2015, therefore, more than 66000 foreign students study in Ukraine, but there were 53664 in 2011 [15].

\section{Conclusions}

The research defined the need to regulate the requirements for the language of instruction and its level of knowledge. Foreign students need to know what language they will learn (Ukrainian, Russian or English) and, if it is possible, begin to assimilate it before coming to Ukraine. After all, the responsibility for learning a language of instruction lies entirely on the "shoulders" of students, and not of universities, throughout the civilized world. European universities generally offer optional courses for studying English or another European language. 
At the same time, the regional dimension of academic mobility and migration demonstrates the existence of a number of contradictions in the implementation of modernization processes in the field of higher education. The analysis of the legislation has demonstrated the crisis nature of the normative provision of academic mobility processes, reinforced by a complex geopolitical situation. Directly the processes of academic mobility and academic migration have "marginalized" status, despite globalization and current geopolitical challenges.

\section{References}

[1] Aba, D. 2016. Addressing Intercultural Experience and Academic Mobility in Higher Education. Journal of Intercultural Communication Research. 45(6):487-502.

[2] Bazaluk, O. and D. Svyrydenko. 2017. Philosophy of war and peace: in search of new European security strategy. Anthropological Measurements of Philosophical Research. 12:89-99.

[3] Breen, M. 2012. Privileged migration: American undergraduates, study abroad, academic tourism. Critical Arts. 26(1):82-102.

[4] Chen, Q., Koyama, J. P. 2013. Reconceptualising diasporic intellectual networks: mobile scholars in transnational space. Globalisation, Societies and Education. 11(1):23-38.

[5] Cullen, J. 2016. Migrants and the language of instruction: Is the EU policy deficit driving new innovations in social inclusion? International Review of Education. 63(4):453-474.

[6] Danylova, T. and G. Salata. 2018. The Ecological Imperative and Human Nature: A New Perspective on Ecological Education. Interdisciplinary Studies of Complex Systems. 12:17-24.

[7] Ennser-Kananen, J. and N. Pettitt. 2017. "I want to speak like the other people": Second language learning as a virtuous spiral for migrant women? International Review of Education. 63(4):583-604.

[8] Faist, T. 2013. The mobility turn: a new paradigm for the social sciences? Ethnic and Racial Studies. 36(11):1637-1646.

[9] Fahey, J. and J. Kenway. 2010. Thinking in a 'worldly' way: mobility, knowledge, power and geography. Discourse: Studies in the Cultural Politics of Education. 31(5):627-640.

[10] Fang, L., R.C.F. Sun and M. Yuen. 2017. "Be useful to society": parental academic involvement in rural to urban migrant children's education in China. Asia Pacific Education Review. 18(3):361-371.

[11] Kim, T. 2009. Transnational academic mobility, internationalization and interculturality in higher education. Intercultural Education. 20(5):395405.

[12] Krichevsky, S. 2017. A Management Concept of the Technosphere's Evolution. Philosophy and Cosmology. 18:153-164.

[13] Kyvliuk, O. and D. Svyrydenko. 2017. Academic mobility as "brain drain" phenomenon of modern higher education. Studia Warminskie. 54:361-371.

[14] Lysak, O. B. 2016. Osvita inozemciv v Ukraini: suchasniy stan, problemy ta marketyngoviy pogliad na shliahy yih podolannya. Visnyk Vinnytskogo politekhnichnogo instytutu. 4:102-107. 
[15] Minosvity nazvalo kilkist inozemnyh studentiv v ukrayinskyh VNZ. https://informator.news/minosvity-nazvalo-kilkist-inozemnyhstudentiv-v-ukrajinskyh-vnz/

[16] Naukkarinen, O. 2005. Aesthetics and Mobility? A Short Introduction into a Moving Field. http://www. contempaesthetics.org/newvolume/ pages/article.php?articleID=350

[17] Potts, A. 2004. Academic migration during the 'golden age of higher education'. Journal of Educational Administration and History. 36(1):35-45.

[18] Rogatynska, O. and D. Dmytri. 2016. Osoblyvosti adaptacii studentiv-inozemciv u VNZ Ukrainy. III Scientific conference actual problems in international students teaching and learning in Ukraine international. Ternopil, Ukraine, May 18-20, 2016. http://elartu.tntu.edu.ua/bitstream/123456789/17005/2/Conf_ 2016_Rogatynska_0-Peculiarities_of_adaptation_199-203.pdf

[19] Shevelev, G. E. 2012. Problemy adaptacii inostrannyh studentov k obucheniyu v Rossii. Sovremennyye problemy nauki i obrazovaniya. 3. http: //www.science-education.ru/ru/article/view?id=6219

[20] Sviatenko, Yu. and T. Seredyuk. 2018. Method of "Childhood" project for the study of the emotional state of children from the ATO zone. Interdisciplinary Studies of Complex Systems. 12:48-56.

[21] Svyrydenko, D. 2014. Akademichna mobilnist: vidpovidi na vyklyky globalizatsii. http://enpuir.npu.edu.ua/bitstream/123456789/6418/ 3/Akadem\%D1\%96chna\%20mob\%D1\%961n\%D1\%96st.pdf

[22] Svyrydenko, D. 2015. Globalization as a factor of academic mobility processes expanding. Philosophy and Cosmology. 14:223-235.

[23] Svyrydenko, D. 2017. Divided Universities: The Postcolonial Experience of Contemporary Ukrainian Higher Education. Future Human Image. 7:128135.

[24] Svyrydenko, D. 2016. Mobility Turn in Contemporary Society as an Educational Challenge. Future Human Image. 6:102-108.

[25] Voronkova, V. and O. Kyvliuk. 2017. Philosophical Reflection SmartSociety as a New Model of the Information Society and its Impact on the Education of the 21st Century. Future Human Image. 7:154-162.

[26] Yablokov, A., V. Levchenko and A. Kerzhentsev. 2016. The Biosphere as a Living System. On Peculiarities of the Evolutionary Process on the Biosphere Level. Philosophy and Cosmology. 17:152-175.

[27] Yevtukh. V. 2013. New Immigrants in Ukrainian Space: Problems of Integration. In: Educaţia Din Perspectiva Valorilor. Idei, Concepte, Modele. Mândâcanu Virgil, Scheau Ioan, Opriş Dorin (editori). Tom IV: Summa Paedsgogica: $34-44$. 